\title{
MODEL TRANSFER PENGETAHUAN ARSITEKTUR TRADISIONAL RUMAH GADANG MINANGKABAU
}

\author{
Rozi Fitriza \\ Tadris Matematika Fakultas Tarbiyah dan Keguruan UIN IB Padang \\ Mahasiswa Sekolah Pascasarjana UPI Bandung
}

Dikirim: 31 Januari 2018; Diterima: 28 Februari 2018; Dipublikasikan: 31 Maret 2018

\begin{abstract}
ABSTRAK
Keberadaan Rumah Gadang, sebagai rumah adat suku Minangkabau, tidak terlepas dari peran tukang tuo yang tetap menjaga keunikan teknik arsitektur tradisional Rumah Gadang. Agar eksistensi Rumah Gadang tetap terjaga, maka harus ada usaha pewarisan pengetahuan arsitektur tradisional. Tulisan ini bertujuan menggambarkan proses transfer pengetahuan arsitektur tradisional Rumah Gadang dari tukang tuo ke generasi penerusnya. Data mengenai proses transfer pengetahuan ini penulis peroleh melalui wawancara dengan tukang tuo. Hasil wawancara menunjukkan 3 (tiga) tahapan utama dalam proses transfer pengetahuan arsitektur tradisional Rumah Gadang. Tahapan proses transfer pengetahuan tersebut bersesuaian dengan teori belajar sosial dan teori belajar sosio-kultural. Hal ini menunjukkan bahwa sangat memungkinkan untuk menjaga kelestarian teknik arsitektur tradisional Rumah Gadang sebagai sebuah local genius.
\end{abstract}

Kata kunci: transfer pengetahuan arsitektur tradisional, teori belajar sosial, teori belajar sosiokultural. 


\section{PENDAHULUAN}

Sumareta Barat (dikenal dengan nama Minangkabau) merupakan daerah yang kaya dengan budaya, adat istiadat. Salah satu unsur budaya Minangkabau yang secara lahiriah tampak sebagai ciri khasnya adalah Rumah Gadang. Rumah Gadang Minangkabau adalah sejenis rumah panggung yang secara fisik berukuran besar serta terdiri dari beberapa ruang. Ciri khas Rumah Gadang yang sangat menonjol adalah bentuk atapnya yang melengkung dan menjulang pada kedua ujungnya, sehingga kalau dillihat dari depan menyerupai tanduk kerbau yang disebut gonjong. Oleh sebab itu Rumah Gadang disebut juga Rumah Gonjong.

Proses pembangunan arsitektur tradisional Rumah Gadang tidak terlepas dari peran tukang tradisional Rumah Gadang (disebut tukang tuo). Bagaimana mereka menerjemahkan falsafah adat minangkabau menjadi bentuk-bentuk geometri yang indah. Tukang tradisional pada umumnya tidak menempuh sekolah formal arsitektur. Bahkan banyak diantara mereka yang hanya menempuh pendidikan formal sampai Sekolah Dasar (SD) dan Sekolah Menengah Pertama (SMP). Tetapi mengeksplorasi "everyday cognition" dari aktivitas dan pelakunya menjadi sebuah kajian yang menarik untuk dilakukan.

Tukang tuo memiliki peran penting dalam proses pembangunan Rumah Gadang. Tukang tuo memiliki peran sebagai designer, pekerja dan supervisor, dengan beberapa tugas, yaitu: dimulai dari menentukan lokasi pendirian Rumah Gadang, memilih bahan bangunan dan proses pengawetan tonggak/kayu sekaligus sebagai tukang yang membangun rumah.

Ukuran Rumah Gadang, ditentukan berdasarkan jumlah ruang (berjumlah ganjil) yang diminta yang punya rumah. Satuan ukuran panjang yang digunakan adalah eto/hasta bundo kanduang yang punya rumah atau hasta tukang tuo. Untuk ukuran panjang, lebar dan tinggi Rumah Gadang ada juga beberapa tukang tuo yang menggunakan prinsip "tajuraba". Dimana jumlah ukuran panjang, lebar dan tinggi rumah tidak boleh berupa bilang genap.

Pembangunan Rumah Gadang ditandai dengan prosesi mancacak paek, yaitu pemahatan pertama pada tonggak tuo yang dilakukan oleh tukang tuo. Tonggak dibuat berbentuk prisma segi-n beraturan. pada umumnya berbentuk prisma segi-6, segi-8 atau segi-12. Proses membentuk tonggak secara arsitektur tradisional dilakukan menggunakan pahat. Setelah itu pemahatan tonggak tuo dilanjutkan sampai lubang-lubang yang akan berfungsi sebagai pengunci rasuak dan palanca di beberapa titik selesai dikerjakan. Mancacak paek sendiri dianggap sebagai proses yang sangat penting karena dengan begitu akan diketahui tinggi lantai dari tanah, tinggi plafon dan dapat diperkirakan berapa tinggi atap sehingga tukang tuo dapat memperkirakan dan membayangkan proporsi tinggi dan lebar bangunan.

Terkait dengan bentuk rumah gadang yang besar ke atas, lubang-lubang pengunci ada yang tidak mengikuti kelurusan tonggak melainkan agak miring dengan sudut kemiringan tertentu. Pekerjaan melubangi tonggak dilanjutkan dengan perangkaian tonggak dengan kemiringan tonggak (91 -94 ) yang dilakukan menurut urutan dari depan ke belakang. Tiang-tiang dari depan ke belakang ini disambung dengan rasuak bawah dan rasuak ateh. Sesudah keenam rangkaian selesai disusun, satu per satu rangkaian tersebut ditegakkan dengan prosesi batagak rumah yaitu menegakkan rangkaian tonggak. Rangkaian tonggak ditarik dengan menggunakan tali yang disebut tali dondan dan ditopang dengan kayu penopang yang disebut kayu juang. Penarikan dimulai dari rangkaian dimana terdapat tonggak tuo dan dilakukan secara bergotong royong. Dengan berdirinya keseluruhan rangkaian tiang, pekerjaan struktur utama rumah gadang dinyatakan selesai yang diakhiri dengan pemasangan sandi pada setiap tonggak. Sandi dipasang dengan cara mengungkit tonggak satu per satu dengan menggunakan kayu pengungkit, kemudian baru disorongkan batu pipih yang digunakan sebagai sandi tersebut.

Tahap selanjutnya adalah tahap penyelesaian yang dimulai pada bagian atap. Dimulai dengan pemasangan kasau yang berjumlah ganjil (21, 23,25 buah). Selanjutnya pemasangan lae, dengan jarak antaranya 3 jari. Penyelesaian atap ini meliputi pemasangan hiasan pada ujung 
gonjong dan parabuangan, yang kemudian dilanjutkan dengan pemasangan ijuak sebagai penutup atap. Ijuak dipasang dua lapis yaitu lapisan dalam berupa ijuak kasa dan lapis terluar ijuak halui. Kemudian dipasang ijuk, dengan tebal pada bagian ujung atap. Pemasangan ijuk menggunakan arah yang sama.

Pekerjaan pembangunan rumah gadang dilanjutkan dengan pengerjaan lantai, mulai dari struktur lantai hingga pelapisnya. Struktur lantai yang terdiri dari balok-balok yang disebut jariau dikunci oleh balok yang terletak di atas rasuak yang disebut sigitan. Setelah balok-balok lantai ini selesai dipasang, barulah lantai dilapisi dengan palupuah halui yang langsung diletakkan di atas jariau dan palupuah kasa pada bagian atasnya.

Pemasangan dinding beserta bukaan pintu dan jendela menjadi tanda bahwa pengerjaan pembangunan rumah gadang sudah hampir selesai. Pekerjaan ini dilakukan setelah lantai dikerjakan. Pemasangan dinding dimulai dari bagian dinding lapisan luar. Sebagai akses naik turun rumah, tangga (dengan anak tangga berjumlah ganjil) menjadi bagian yang sangat penting dari rumah gadang. Tangga dibuat dimana sudut yang dibentuk antara tanah dengan tangga lebih dari 45 derajat agar waktu untuk naik turun tidak begitu lama. Dengan berakhirnya pembuatan tangga, selesailah keseluruhan proses pekerjaan pembangunan dan rumah gadang pun siap untuk dihuni. Sebagai tanda bahwa rumah sudah siap untuk dihuni, diadakanlah prosesi manaiki rumah.

Kompetensi yang dimiliki tukang tuo dalam menciptakan arsitektur tradisional agar tetap selaras dengan falsafah adat Minangkabau perlu tetap dipertahankan, agar nilai-nilai yang terkandung dalam bentuk geometri Rumah Gadang tetap terjaga. Untuk itu perlu adanya transfer pengetahuan arsitektur tradisional dari tukang tuo ke generasi selanjutnya.

Tulisan ini menguraikan tentang proses transfer pengetahuan arsitektur tradisional dari tukang tuo ke generasi selanjutnya, sebagai bentuk pewarisan kearifan lokal. Karena tulisan ini ditujukan untuk kajian pedagogi dalam kajian Ethnomathematics, maka ide-ide matematis yang digunakan tukang tuo dalam membangun Rumah Gadang dijadikan sebagai ilustrasi dalam menggambarkan proses transfer pengetahuan tersebut. Selanjutnya dibahas teori belajar sosial dan teori belajar sosio-kultural, yang berkaitan dengan proses pembelajaran dalam konteks sosial budaya. Untuk selanjutnya teori-teori belajar tersebut dikaitkan dengan proses transfer pengetahuan arsitektur tradisional oleh tukan tuo. Diharapkan bahasan ini dapat menjadi awal menemukan model atau pola yang efektif dalam rangka pewarisan nilai-nilai dan budaya dalam masyarakat.

\section{PROSES TRANSFER PENGETAHUAN ARSITEKTUR TRADISIONAL RUMAH GADANG}

Proses transfer pengetahuan dari tukang tuo ke generasi penerusnya, yaitu tukang muda yang menaruh minat terhadap arsitektur tradisional dilakukan, dengan mengikutsertakan tukang muda dalam proses pembangunnan Rumah Gadang. Adapun gambaran transfer pengetahuan dilakukan sebagai berikut:

1. Memberi contoh teknik pertukangan

Pada tahap ini tukang tuo memberikan contoh cara kerja bagian-bagian dari proses pembangunan Rumah Gadang. Tukang muda memperhatikan tahapan-tahapannya, dan jika ada yang tidak dimengerti bertanya kepada tukang tuo. Tahap awal pengerjaan rumah dimulai dari pemahatan tonggak tuo, ini dilakukan oleh tukang tuo melalui acara batagak tonggak tuo. Untuk tonggak-tonggak rumah yang lain juga akan dipahat dan dibentuk seperti prisma segi-n. tonggak rumah yang biasa ditemukan adalah tonggak segi-6, segi-8 dan segi-12. Cara yang dilakukan untuk membuat prisma segi-n beraturan tersebut adalah dengan mengukur keliling tonggak dengan membalutkan daun nipah/tali sekeling tonggak. Setelah itu, hasil dari keliling tonggak tersebut dilipat menjadi 2 bagian yang sama yang merupakan keliling tonggak. Jika akan membuat menjadi prisma segi-6, maka yang $1 / 2$ keliling tadi dibagi menjadi 3 bagian yang sama panjang. Hasil yang didapat merupakan panjang untuk 1 rusuk prisma segi-6. Setelah itu baru dilakukan pemahatan berdasarkan ukuran yang didapat. 
2. Meminta tukang muda untuk mencoba teknik pertukangan yang telah diajarkan.

Setelah tukang tuo memberikan contoh cara kerja, selanjutnya tukang muda diminta mempraktekkan apa-apa yang telah diajarkan. Pada proses ini tukang muda tetap di bawah pengawasan dan arahan tukang tuo. Tukang muda belum bisa bekerja sendiri, masih membantu tukang tuo. Proses pertukangan yang rumit, misalnya dalam pemasangan atap belum bisa dilakukan tukang muda.

Tukang muda dapat mencoba melakukan penyusunan/merangkai tonggak yang telah dipahat tadi, sebelum didirikan. Satu baris terdiri dari 6 tonggak dengan 3 macam bentuk. Untuk menyamakan kemiringan tonggak ( $91^{\circ}-94$ ) tukang tuo menggantungkan tali/menggunakan galah pada bagian atas tonggak, kemudian mengukur dengan tali panjang sisi mendatar (ruas garis antara pangkal tonggak dan ujung tali. (sisi segitiga siku-siku terpendek). Ukuran-ukuran tersebut dijadikan patokan untuk menyamakan kemiringan tonggak-tonggak.

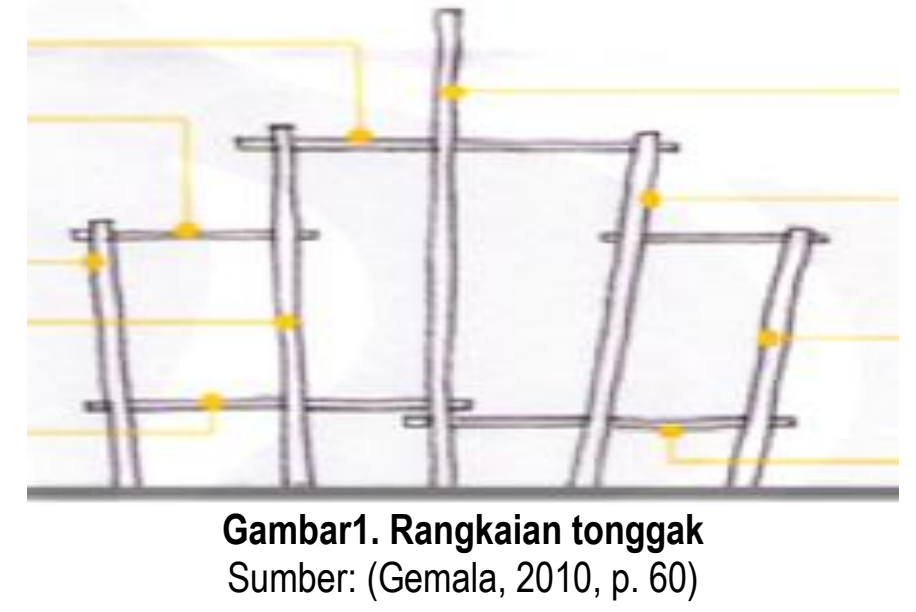

3. Meminta tukang muda untuk praktek sendiri, dengan pengawasan dari tukang tuo serta memberikan prinsip-prinsip dasar pembangunan rumah.

Pada tahap ini tukang muda sudah bisa bekerja sendiri. Tukang muda juga sudah diberikan tanggung jawab terhadap teknik-teknik yang rumit, seperti pemasangan atap/gonjong, tetapi tetap dalam pengawasan tukang tuo.

Selanjutnya pembuatan atap, dimulai dengan pemasangan kasau yang berjumlah ganjil (21, 23, 25 buah). Selanjutnya pemasangan lae, dengan jarak antaranya 3 jari. Kelengkungan atap digunakan prinsip alua jo patuik (falsafah dan estetika). Prinsip ini dimiliki oleh tukang tuo berdasarkan keilmuan yang ia dapat dari pengalaman. Ketika mengajarkan membuat kelengkungan atap tukang muda diminta untuk mengerjakannya, sementara tukang tuo mengarahkan dari bawah. Kemudian dipasang ijuk, dengan tebal pada bagian ujung atap. Pemasangan ijuk menggunakan arah yang sama.

Prinsip dasar arsitektur tradisional dalam pembangunan rumah Gadang, termasuk mengenai ukuran-ukuran panjang, lebar dan tinggi rumah. Ukuran panjang rumah ditentukan oleh banyaknya ruang (berjumlah ganjil 3, 5, 7 atau 9) yang dibutuhkan. Sedangkan lebar rumah ditentukan oleh lanjar. Lanjar rumah yang lengkap terdiri dari 4 bagian, yaitu: balai, labuah, bandua, dan biliak. Tukang tuo memiliki pengalaman untuk menentukan ukuran-ukuran tersebut. Jika panjang rumah 21 eto, maka lebar 14 eto atau jika panjang 24 eto maka 16 eto. Tinggi rumah berdasarkan aspek estetika yang dimiliki tukang tuo (alua jo patuik) (hasil wawancara dengan tukang tuo Pak Suwat, Agustus 2016).

Sedangkan tukang tuo lainnya (Dasrul Dt. Sati nan panjang) menggunakan prinsip ilmu "tajaruba" dalam menentukan ukuran rumah. Jika panjang rumah 18 eto/hasta, lebar 12 eto, tinggi 8 eto. Apabila dijumlahkan semua ukuran tersebut berjumlah 38 eto. Hal ini tidak diperbolehkan, karena jumlah panjang, lebar dan tingginya genap. Selanjutnya jumlah ini 
dikonfersi menjadi 35 eto. Selanjutnya 38 eto -35 eto $=3$ eto. Maka untuk tiap-tiap ukuran tersebut dilebihkan atau dikurangi tidak melebihi 3 eto.

Anak tangga rumah gadang berjumlah ganjil. Untuk menentukan jarak antara anak tangga digunakan tali. Dimulai dengan mengukur panjang tangga secara keseluruhan, setelah itu membagi tali tersebut menjadi bagian yang sama panjang ( 5 atau 7 bagian). Tangga dibuat dimana sudut yang dibentuk antara tanah dengan tangga lebih dari 45 derajat agar waktu yang dibuhkan untuk naik turun tidak begitu lama.

Demikianlah secara umum gambaran proses transfer pengetahuan dari tukang tuo kepada tukang muda. Proses belajar ini dilakukan dimana tukang muda dibawa ikut serta dalam suatu kerja pembangunan Rumah Gadang. Setelah tukang muda dianggap telah menguasai teknik pertukangan tradisional dan prinsip-prinsip dasar dari bentuk Rumah Gadang yang sesuai dengan falsafah suku Minangkabau (seperti menentukan ukuran-ukuran panjang rumah atau bentuk/kelengkungan atap), maka tukang muda tadi dapat dilepas ke masyarakat untuk mempraktekkan ilmunya.

Bentuk evaluasi dari proses transfer pengetahuan arsitektur tradisional ini bersifat alamiah. Artinya ketika generasi penerus arsitektur tradisional tadi dilepas ke masyarakat, masyarakat pengguna jasa merasa puas dengan hasil kerjanya. Tetapi apabila tukang muda tadi mendapat sanksi sosial dari masyarakat misalnya berupa kritik terhadaap hasil karyanya atau tidak digunakan lagi jasanya, maka menunjukkan bahwa ia belum menguasai teknik arsitektur yang diajarkan.

\section{TEORI BELAJAR SOSIAL}

Teori belajar sosial (teori observasional) merupakan perluasan dari teori belajar prilaku. Teori ini dikembangkan oleh Albert Bandura. Dalam teori belajar sosial ini menggunakan istilah reinforcement eksternal dan kognitif internal untuk memahami bagaimana seseorang belajar dari orang lain. Melalui observasi dan interpretasi kognitif terhadap lingkungan sosial, dapat diperoleh informasi dan penampilan keahlian yang kompleks dapat dipelajari.

Dalam pandangan belajar sosial, manusia tidak didorong oleh kekuatan atau stimulus dari dalam, namun dipengaruhi fungsi psikologi. Fungsi psikologi sebagai interaksi yang kontinu dan timbal balik dari determinan pribadi dan determinan lingkungan (A.Bandura, 1971). Teori belajar sosial menganalisis hubungan kontinu antara lingkungan, ciri-ciri pribadi, dan perilaku terbuka dan tertutup seseorang.

Teori belajar sosial menggunakan prinsip modeling. Pemodelan yang dimaksud yaitu meniru prilaku orang lain dan pengalaman "vicarious" (belajar dari keberhasilan dan kegagalan orang lain). Fase belajar menggunakan pemodelan ini adalah: (Dahar, 2011, pp. 23-25)

1. Fase Perhatian

Fase pertama dalam belajar observasional, adalah memperhatikan model yang ada. Model yang biasa menjadi perhatian siswa adalah model yang menarik, berhasil, memberikan motivasi dan popular. Untuk itu guru dituntut agak dapat menciptakan hal-hal baru yang tak terduga sehingga membangkitkan minat dan perhatian siswa.

2. Fase Retensi

Bandura berpendapat bahwa kata-kata, nama-nama atau bayangan yang dikaitkan dengan kegiatan-kegiatan yang dimodelkan, memiliki pengaruh yang sangat penting dalam mempelajari dan mengingat perilaku. Materi pelajaran akan lama diingat bila terjadi pengulangan terbuka. Pembelajaran dengan teori belajar sosial seringkali melakukan pengulangan tertutup. Dimana pebelajar mengingat unsur-unsur pokok dari perilaku yang harus dikuasai. Pengulangan tertutup menolong terbentuknya kesesuaian antara perilaku pebelajar dengan model yang diamati.

3. Fase Reproduksi

Pada fase ini kode-kode simbolik verbal dalam memori, membimbing perilaku dari pebelajar dari apa yang baru diperolehnya. Derajat ketelitian yang tertinggi dalan belajar observasional terjadi bila tindakan mengikuti pengulangan secara mental. Fase reproduksi mengizinkan model untuk 
melihat apakah komponen-komponen suatu urutan perilaku yang telah diaajarkan telah sesuai dengan konsep sebenarnya. Dalam hal ini umpan balik merupakan hal yang penting dalam rangka memperbaiki kesalahan yang dibuat siswa untuk membentuk perilaku yang diinginkan. Secara cepat diberikan respon terhadap tindakan siswa yang tidak/kurang tepat, mencegahnya untuk berkembang menjadi kebiasaan yang tidak diinginkan.

4. Fase Motivasi

Para siswa meniru model, dengan harapan jika berbuat seperti itu, meningkatkan kemungkinan mereka memperoleh penghargaan. Perhargaan yang dapat diterima berupa pujian atau nilai yang bagus. Sehingga siswa dalam tahap ini berupaya untuk mendapatkan penghargaan dengan memperhatikan model (guru) dengan seksama.

Bandura berhipotesis bahwa manusia melakukan pengamatan terhadap dirinya sendiri, kemudian melakukan penilaian terhadap kinerjanya, sesuai dngan kriteria yang ditetapkan sendiri, untuk selanjutnya dapat memberikan penghargaan atau hukuman terhadap diri sendiri. Teori belajar sosial memandang bahwa kriteria keberhasilan yang kita tetapkan dapat dipelajari dari modelmodel yang ada dalam kehidupan sosial.

\section{TEORI BELAJAR SOSIO-KULTURAL}

Teori belajar sosio-kultural atau yang juga dikenal sebagai teori belajar ko-kontruktivistik merupakan teori belajar yang titik tekan utamanya adalah pada bagaimana seseorang belajar dengan bantuan orang lain dalam suatu zona keterbatasan dirinya yaitu Zona Proksimal Development (ZPD) atau Zona Perkembangan Proksimal dan mediasi. Di mana anak dalam perkembangannya membutuhkan orang lain untuk memahami sesuatu dan memecahkan masalah yang dihadapinya.

Teori yang juga disebut sebagai teori konstruksi sosial ini menekankan bahwa intelegensi manusia berasal dari masyarakat, lingkungan dan budayanya. Teori ini juga menegaskan bahwa perolehan kognitif individu terjadi pertama kali melalui interpersonal (interaksi dengan lingkungan sosial) intrapersonal (internalisasi yang terjadi dalam diri sendiri). Vygotsky berpendapat bahwa menggunakan alat berfikir akan menyebabkan terjadinya perkembangan kognitif dalam diri seseorang. Yuliani (2005: 44) secara spesifik menyimpulkan bahwa kegunaan alat berfikir menurut Vygotsky adalah:

1. Membantu memecahkan masalah

Alat berfikir mampu membuat seseorang untuk memecahkan masalahnya. Kerangka berfikir yang terbentuklah yang mampu menentukan keputusan yang diambil oleh seseorang untuk menyelesaikan permasalahan hidupnya.

2. Memudahkan dalam melakukan tindakan

Vygotsky berpendapat bahwa alat berfikirlah yang mampu membuat seseorang mampu memilih tindakan atau perbuatan yang seefektif dan seefisien mungkin untuk mencapai tujuan.

3. Memperluas kemampuan

Melalui alat berfikir setiap individu mampu memperluas wawasan berfikir dengan berbagai aktivitas untuk mencari dan menemukan pengetahuan yang ada di sekitarnya.

4. Melakukan sesuatu sesuai dengan kapasitas alaminya.

Semakin banyak stimulus yang diperoleh maka seseorang akan semakin intens menggunakan alat berfikirnya dan dia akan mampu melakukan sesuatu sesuai dengan kapasitasnya.

Inti dari teori belajar sosiokultural ini adalah penggunaan alat berfikir seseorang yang tidak dapat dilepaskan dari pengaruh lingkungan sosial budayanya. Lingkungan sosial budaya akan menyebabkan semakin kompleksnya kemampuan yang dimiliki oleh setiap individu.

Guruvalah berpendapat bahwa teori-teori yang menyatakan bahwa "siswa itu sendiri yang harus secara pribadi menemukan dan menerapkan informasi kompleks, mengecek informasi baru dibandingkan dengan aturan lama dan memperbaiki aturan itu apabila tidak sesuai lagi". 
Teori belajar Sosiokultural ini menekankan bahwa perubahan kognitif hanya terjadi jika konsepsikonsepsi yang telah dipahami diolah melalui suatu proses ketidakseimbangan dalam upaya memakai informasi-informasi baru. Teori belajar sosiokultural meliputi tiga konsep utama, yaitu:

1. Hukum genetik tentang perkembangan

Perkembangan menurut Vygotsky tidak bisa hanya dilihat dari fakta-fakta atau keterampilanketerampilan, namun lebih dari itu, perkembangan seseorang melewati dua tataran. Tataran soaial tempat orang-orang membentuk lingkungan sosialnya (dapat dikategorikan sebagai interpsikologis atau intermental), dan tataran sosial di dalam diri orang yang bersangkutan (dapat dikategorikan sebagai intrapsikologis atau intramental).

Teori sosiokultural menempatkan intermental atau lingkungan sosial sebagai faktor primer dan konstitutif terhadap pembentukan pengetahuan serta perkembangan kognitif seseorang. Fungsifungsi mental yang tinggi dari seseorang diyakini muncul dari kehidupan sosialnya. Sementara itu, intramental dalam hal ini dipandang sebagai derivasi atau turunan yang terbentuk melalui penguasaan dan internalisasi terhadap proses-proses sosial tersebut. Hal ini terjadi karena anak baru akan memahami makna dari kegiatan sosial apabila telah terjadi proses internalisasi. Oleh sebab itu belajar dan berkembang satu kesatuan yang menentukan dalam perkembangan kognitif seseorang.

Seperti yang dikutip oleh Yuliani (2005: 44) Vygotsky meyakini bahwa kematangan merupakan prasyarat untuk kesempurnaan berfikir. Secara spesifik, namun demikian ia tidak yakin bahwa kematangan yang terjadi secara keseluruhan akan menentukan kematangan selanjutnya.

2. Zona perkembangan proksimal

Zona Perkembangan Proksimal/Zona Proximal Development (ZPD) merupakan konsep utama yang paling mendasar dari teori belajar sosiokultural Vygotsky. Dalam Luis C. Moll (1993: 156157), Vygotsky berpendapat bahwa setiap anak dalam suatu domain mempunyai "level perkembangan aktual" yang dapat dinilai dengan menguji secara individual dan potensi terdekat bagi perkembangan domain dalam tersebut. Vygotsky mendefinisikan Zona perkembangan proksimal sebagai jarak antara level perkembangan aktual seperti yang ditentukan untuk memecahkan masalah secara individu dan level perkembangan potensial seperti yang ditentukan lewat pemecahan masalah di bawah bimbingan orang dewasa atau dalam kolaborasi dengan teman sebaya yang lebih mampu. Secara jelas Vygotsky memberikan pandangan yang matang tentang konsep tersebut seperti yang dikutip oleh Luis C. Moll (1993: 157):

"Zona Perkembangan Proksimal mendefinisikan fungsi-fungsi tersebut yang belum pernah matang, tetapi dalam proses pematangan. Fungsi-fungsi tersebut akan matang dalam situasi embrionil pada waktu itu. Fungsi-fungsi tersebut dapat diistilahkan sebagai "kuncup" atau "bunga" perkembangan yang dibandingkan dengan "buah" perkembangan."

Yuliani (2005: 45) mengartikan "Zona Perkembangan Proksimal sebagai fungsi-fungsi atau kemampuan yang belum matang yang masih berada pada proses pematangan". Karena fungsi-fungsi yang belum matang ini maka anak membutuhkan orang lain untuk membantu proses pematangannya. Sedangkan I Gusti Putu Suharta dalam makalahnya berpendapat bahwa:

"Zone of Proximal Development (ZPD) merupakan jarak antara tingkat perkembangan sesungguhnya yang didefinisikan sebagai kemampuan pemecahan masalah secara mandiri dan tingkat perkembangan potensial yang didefinisikan sebagai kemampuan pemecahan masalah di bawah bimbingan orang dewasa atau melalui kerjasama dengan teman sejawat yang lebih mampu"

Zona Perkembangan Proksimal terdekat adalah ide bahwa siswa belajar konsep paling baik apabila konsep itu berada pada zona perkembangan terdekat mereka (Guruvalah). 
Sedangkan Marysia (2003) menyatakan bahwa "ZPD merupakan suatu wilayah aktifitas-aktifitas di mana individu dapat mengemudikan dengan kawan-kawan sebaya, orang-orang dewasa, ataupun orang yang lebih ahli yang memiliki kemampuan lebih". Pandangan Vygotsky tentang interaksi antara kawan sebaya dan pencontohan adalah cara-cara penting untuk memfasilitasi perkembangan kognitif individu dan kemahiran pengetahuan.

Dalam makalah lain, Julia berpendapat bahwa "ZPD merupakan level perkembangan yang dicapai ketika anak-anak ikut serta dalam tingkah laku sosial". Hal ini dapat diartikan bahwa perkembangan penuh ZPD tergantung pada interaksi sosial yang penuh, di mana keahlian dapat diperoleh dengan bimbingan oraang dewasa atau kolaborasi antar kawan sebaya ataupun orang yang lebih faham melampaui apa yang difahaminya.

Dalam Yuliani (2005: 45) Vygotsky mengemukakan ada empat tahapan ZPD yang terjadi dalam perkembangan dan pembelajaran yang menyangkut ZPD, yaitu :

Tahap 1. Tindakan anak masih dipengaruhi atau dibantu orang lain.

Seorang anak yang masih dibantu memakai baju, sepatu dan kaos kakinya ketika akan berangkat ke sekolah ketergantungan anak pada orang tua dan pengasuhnya begitu besar, tetapi ia suka memperhatikan cara kerja yang ditunjukkan orang dewasa

Tahap 2. Tindakan anak yang didasarkan atas inisiatif sendiri.

Anak mulai berkeinginan untuk mencoba memakai baju, sepatu dan kaos kakinya sendiri tetapi masih sering keliru memakai sepatu antara kiri dan kanan. Memakai bajupun masih membutuhkan waktu yang lama karena keliru memasangkan kancing.

Tahap 3. Tindakan anak berkembang spontan dan terinternalisasi.

Anak mulai melakukan sesuatu tanpa adanya perintah dari orang dewasa. Setiap pagi sebelum berangkat ia sudah mulai faham tentang apa saja yang harus dilakukannya, misalnya memakai baju kemudian kaos kaki dan sepatu.

Tahap 4. Tindakan anak spontan akan terus diulang-ulang hingga anak siap untuk berfikir abstrak. Terwujudnya perilaku yang otomatisasi, anak akan segera dapat melakukan sesuatu tanpa contoh tetapi didasarkan pada pengetahuannya dalam mengingat urutan suatu kegiatan. Bahkan ia dapat menceritakan kembali apa yang dilakukannya saat ia hendak berangkat ke sekolah.

Pada empat tahapan ini dapat disimpulkan bahwa. Seseorang akan dapat melakukan sesuatu yang sebelumnya tidak bisa dia lakukan dengan bantuan yang diberikan oleh orang dewasa maupun teman sebayanya yang lebih berkompeten terhadap hal tersebut.

\section{Mediasi}

Mediasi merupakan tanda-tanda atau lambang-lambang yang digunakan seseorang untuk memahami sesuatu di luar pemahamannya. Ada dua jenis mediasi yang dapat mempengaruhi pembelajaran yaitu, (1) tema mediasi semiotik di mana tanda-tanda atau lambang-lambang yang digunakan seseorang untuk memahami sesuatu di luar pemahamannya ini didapat dari hal yang belum ada di sekitar kita, kemudian dibuat oleh orang yang lebih faham untuk membantu mengkontruksi pemikiran kita dan akhirnya kita menjadi faham terhadap hal yang dimaksudkan; (2) scaffolding di mana tanda-tanda atau lambang-lambang yang digunakan seseorang untuk memahami sesuatu di luar pemahamannya ini didapat dari hal yang memang sudah ada di suatu lingkungan, kemudian orang yang lebih faham tentang tanda-tanda atau lambang-lambang tersebut akan membantu menjelaskan kepada orang yang belum faham sehingga menjadi faham terhadap hal yang dimaksudkan.

Kunci utama untuk memahami proses sosial psikologis adalah tanda-tanda atau lambanglambang yang berfungsi sebagai mediator. Tanda-tanda atau lambang-lambang tersebut sebenarnya merupakan produk dari lingkungan sosiokultural di mana seseorang berada. Untuk memahami alat-alat mediasi ini, anak-anak dibantu oleh guru, orang dewasa maupun teman sebaya yang lebih faham. Wertsch dalam Yuliani (2005: 45-46) berpendapat bahwa: 
"Mekanisme hubungan antara pendekatan sosiokultural dan fungsi-fungsi mental didasari oleh tema mediasi semiotik. Artinya tanda atau lambang beserta makna yang terkandung di dalamnya berfungsi sebagai penghubung antara rasionalitas-sosiokultural (intermental) dengan individu sebagai tempat berlangsungnyaa proses mental".

\section{PEMBAHASAN}

Tahapan-tahapan yang dilakukan tukang tuo dalam proses transfer pengetahuan tentang arsitektur tradisional meliputi: memberikan contoh tentang teknik pertukangan tradisional, meminta tukang muda untuk mempraktekkan teknik pertukangan yang telah diajarkan dan memberikan kesempatan kepada tukang muda untuk bekerja secara sendiri dengan pengawasan tukang tuo. Tahapan-tahapan ini bersesuaian dengan fase belajar pada teori belajar sosial Albert Bandura. Teori belajar sosial menggunakan prinsip modeling dalam pembelajarannya. Dalam hal ini tukang tuo dijadikan model dalam rangka transfer pengetahuan arsitektur tradisional.

Fase belajar pada teori belajar sosial terdiri dari fase perhatian, fase retensi, fase reproduksi dan fase motivasi. Fase perhatian terlihat juga ketika pada tahap awal belajar arsitektur tradisional. Dengan memperhatikan tukang tuo bekerja, tukang muda memperoleh ilmu tentang bagaimana mendesain dan membangun Rumah Gadang. Rumah Gadang memiliki jumlah ruang yang ganjil, ukuran panjang, lebar dan tinggi yang diukur dengan ketentuan menurut alua jo patuik dari pengalaman tukang tuo. Tonggak rumah juga memiliki kemiringan tertentu, yang menuntut keahlian membuatnya, sehingga prinsip terpenuhi bahwa rumah gadang berbentuk kapal yang besar kearah atas.

Setelah memperhatikan tukang tuo bekerja, tukang muda melakukan pengulangan tertutup dengan mengingat apa-apa yang telah diajarkan kepadanya. Ini merupakan tahapan retensi pada teori belajar sosial. Pada tahap ini tukang muda mengingat kembali pengetahuan yang telah ditransfer, seperti bagaimana cara membentuk tonggak menjadi prisma segi-n beraturan, memahat tonggak sehingga sebangun dengan dengan palanca atau rasuak (kayu penghubung antara tonggak).

Tahap selanjutnya tukang muda diminta untuk melakukan secara mandiri teknik pertukangan yang dipelajari (tahap reproduksi). Dalam hal ini tukang tuo sebagai model memiliki peran untuk melihat apakah tukang muda sudah melakukan urutan-urutan yang benar dalam pekerjaannya, seperti saat batagak tonggak (mendirikan tonggak). Dalam tahap ini tukang tuo dapat memberikan umpan balik terhadap pekerjaan tukang muda, sehingga membentuk kemahiran yang diinginkan.

Tahap motivasi, terlihat dari evaluasi yang dilakukan tukang tuo terhadap kinerja tukang muda. Ketika tukang muda sudah dianggap mahir maka diberi kesempatan/proyek untuk membangun rumah gadang secara mandiri. Tetapi ketika tukang muda belum dianggap mahir, maka dilakukan pembinaan terus menerus. Kesulitan yang biasa dihadapi oleh tukang muda adalah saat membentuk kelengkungan atap. Bagaimana membuat gonjong yang sesuai dengan estetika dan proporsi antara tinggi atap dan bagian rumah tepat.

Berdasarkan gambaran di atas terlihat bahwa Teori Belajar Sosial (Social Learning Theory) digunakan dalam proses transfer pengetahuan teknik arsitektur tradisional dari tukang tuo kepada generasi penerusnya (tukang muda).

Teori belajar sosio-kultural yang dikemukakan oleh Vygotsky, melengkapi teori belajar sosial dalam menggambarkan proses transfer pengetahuan arsitektur tradisional Rumah Gadang. Teori belajar sosio-kultural penekanannya adalah pada bagaimana seseorang belajar dengan bantuan orang lain dalam suatu zona keterbatasan dirinya yaitu Zona Proksimal Development (ZPD) atau Zona Perkembangan Proksimal dan mediasi. Di mana seseorang dalam perkembangannya membutuhkan orang lain untuk memahami sesuatu dan memecahkan masalah yang dihadapinya. Hal ini sejalan dengan prinsip pemodelan yang ada pada teori belajar sosial. Dimana seseorang 
belajar dengan melakukan peniruan melalui fase perhatian dan diperkuat dengan fase retensi dan reproduksi.

Tukang tuo yang merupakan model sekaligus adalah orang lain yang akan memberikan mediasi semiotik dan scaffolding dalam memberikan pengetahuan arsitektur tradisional kepada tukang muda. Mediasi semiotik yaitu tanda-tanda atau lambang-lambang yang digunakan seseorang untuk memahami sesuatu di luar pemahamannya ini didapat dari hal yang belum ada di sekitar kita, kemudian dibuat oleh orang yang lebih faham untuk membantu mengkontruksi pemikiran kita dan akhirnya kita menjadi faham terhadap hal yang dimaksudkan. Tukang tuo memberikan pahatan yang berbeda untuk tiap tiap tonggak, yang menunjukkan berbedanya ukuran pahatan pada tiap tonggak. Selanjutnya tukang tuo memberikan scaffolding berupa penjelasan tentang makna yang dia buat dari pahatan tersebut. Pandangan Vygotsky tentang interaksi antara kawan sebaya dan pencontohan adalah cara-cara penting untuk memfasilitasi perkembangan kognitif individu dan kemahiran pengetahuan.

Sumbangan penting dari teori sosio-kulturalnya Vygotsky adalah penekanan pada hakikat interaksi antara aspek interpersonal (interaksi dengan lingkungan sosial) dan intrapersonal (internalisasi yang terjadi dalam diri sendiri). dari pembelajaran terutama pada lingkungan sosialnya. Fungsi kognitif manusia berasal dari interaksi sosial masing-masing individu dalam konteks budaya. Pembentukan makna tidak hanya terjadi ketika akses pengalaman fisik, tetapi juga interaksi dengan pengalaman yang dimiliki oleh individu lain. Dalam hal ini setelah tukang tuo memberikan contoh teknik pertukangan, maka terjadi internalisasi pengetahuan dalam diri tukang muda, melalui pengulangan-pengulangan pemaknaan pengetahuan.

Pandangan tukang tuo bahwa tukang muda yang memiliki keseriusan dan minat yang kuat untuk mempelajari arsitektur tradisional Rumah Gadang yang dapat berhasil mewariskan pengetahuan dan keterampialn arsitektur tradisional. hal ini sejalan dengan pendapat Vygotsky bahwa kematangan merupakan prasyarat untuk kesempurnaan berfikir. Dalam hal ini kematangan yang dimaksud adalah kesiapan untuk mempelajari arsitektur tradisional tersebut.

\section{REKOMENDASI}

Hasil penelitian ini dapat dijadikan bahan penelitian lebih lanjut dan dijadikan kajian yang lebih mendalam agar generasi muda khususnya yang ada di Sumatera Barat memiliki keseriusan dan minat yang kuat untuk mempelajari arsitektur tradisional Rumah Gadang agar dapat mewariskan pengetahuan dan keterampialn arsitektur tradisional.

\section{UCAPAN TERIMAKASIH}

Peneliti mengucapkan terimakasih kepada Dr. Ir. Syamsul Asri atas referensi dan diskusinya, pada Pak Suwat selaku tukang tuo dan Pak Dasrul Dt. Sati nan Panjang.

\section{KESIMPULAN}

Proses transfer pengetahuan dan keterampilan mengenai arsitektur tradisional Rumah Gadang dari tukang tuo ke generasi penerusnya dapat digambarkan menggunakan teori belajar sosial dan teori belajar sosio-kultural. Berdasarkan teori belajar sosial, tukang tuo diposisikan sebagai model yang menjadi acuan bagi tukang muda dalam melakukan teknik pertukangan. Dalam teori sosiokultural tukang tuo merupakan seseorang yang memiliki keahlian yang dapat memberikan scaffolding dalam pencapaian zona perkembangan proksimal tukang muda.

Penguatan pengetahuan dilakukan melalui fase retensi dan reproduksi dengan pemberian bantuan dan umpan balik oleh tukang tuo. Dengan demikian proses internalisasi dan perkembangan pengetahuan memberikan penguatan kognitif tukang muda. Penggunaan prinsip-prinsip dari teori belajar sosial dan teori belajar sosio-kultural ini diharapkan dapat membantu proses pewarisan kearifan lokal berupa arsitektur tradisional dan local genius dalam aspek matematika. 


\section{DAFTAR PUSTAKA}

A.Bandura. (1971). Social Learning Theory. New York: General Learning Press.

Dahar, R. (2011). Teori-teori belajar dan Pembelajaran. Jakarta: Erlangga.

Gemala. (2010). Arsitektur Vernakular Minangkabau. Jakarta: Departemen Arsitektur FT UI.

Guruvalah. tanpa tahun. Teori-teori Psikologi Belajar. www.geocities.com/guruvalah/ psikologi_belajar.pdtf-Hasil Tambahan.

Johnson, Marysia. (2003). Social Development Theory (L. Vygotsky). Marysia Johnson : Lin 591 : Vygotsky"s.

Moll, Luis C. (1993). Vygotsky \& Education Instructional Implications and Applications of Sociohistorical Psychology. Australia : Cambridge University Press.

Yuliani Nurani Sujiono, dkk. III. (2005). Metode Pengembangan Kognitif. Jakarta : Pusat Penerbitan Universitas Terbuka. 
•84 Jurnal Teori dan Riset Matematika (TEOREMA) Vol. 2 No. 2, Hal, 84-84, Maret 2018

Cara sitasi: Fitriza, R. 2018. Model Transfer Pengetahuan Arsitektur Tradisional Rumah Gadang Minangkabau. Teorema: Teori dan Riset Matematika Vol 2, No 2 (2018). Hal 73-84 